\title{
Synthesis, spectroscopic and crystal structure analysis of a compound with pharmocophoric substituent: 2-cyclohexyl-6-(2-oxo-2H-chromen-3-yl)- imidazo $[2,1-b][1,3,4]$ thiadiazole-5-carbaldehyde
}

\author{
Noor Shahina Begum, ${ }^{(1) *}$ D. E. Vasundhara, ${ }^{(1)}$ C. R. Girija, ${ }^{(1)}$ G. D. Kolavi, ${ }^{(2)}$ \\ V. S. Hegde, ${ }^{(2)}$ and I. M. Khazi ${ }^{(2)}$
}

Received April 4, 2006; accepted September 29, 2006

Published Online February 3, 2007

Imidazo[2,1-b][1,3,4] thiadiazole derivatives are significant for their various pharmacological properties. This paper reports the synthesis and structure of one of them, 2-cyclohexyl6-(2-oxo-2H-chromen-3-yl)imidazo[2,1-b][1,3,4]thiadiazole-5-carbaldehyde. The compound crystallizes in the monoclinic space group $\mathrm{P} 22_{1} / \mathrm{c}$ with $a=17.316(3) \AA$, $b=6.5420(9) \AA, \quad c=17.056(3) \AA, \quad \beta=112.909(2)^{\circ}, \quad V=1779.7(4) \AA^{3}, \quad z=4 . \quad$ The, Imidazo[2,1-b][1,3,4] thiadiazole and the coumarin ring systems are each planar but inclined at an angle of $48.14(2)^{\circ}$ towards each other. The crystal structure is stabilized by $\mathrm{C}-\mathrm{H} \ldots \mathrm{O}$ interactions.

KEY WORDS: Imidazo[2,1-b][1,3,4] thiadiazole derivatives; Coumarin; Vilsmeier-Haack reaction; crystal structure analysis.

\section{Introduction}

Imidazo[2,1-b][1,3,4] thiadiazole (IT) deriva tives with pharmacophoric substituents have promising biological and pharmacological activities. The title compound is one of such derivatives, with a coumarin molecule linked to the IT ring system.

The IT ring is bioisosteric with the Imidazo[2,1-b]thiazole ring present in the well known anthelmintic drug 'Tetramisole.' 1 In this regard, a large number of IT derivatives have been

\footnotetext{
(1) Department of Studies in Chemistry, Bangalore University, Central College Campus, Bangalore 560001, India.

(2) Department of Chemistry, Karnatak University, Dharwad 580003, India.

* To whom correspondence should be addressed; e-mail: noorsb@ rediffmail.com
}

reported to possess diverse pharmacological properties viz., antibacterial, ${ }^{2}$ analgesic ${ }^{3}$ and anthelmintic ${ }^{4}$ activities. Coumarin derivatives are also found in varieties of natural products ${ }^{5}$ and many of them display pharmacological properties. $^{6-9}$ Apart from this, coumarins are of considerable general importance and are prominent in natural products chemistry. They have been found to possess a wide variety of uses in the perfume industry, as flavor enhancers, sunscreens and laser dyes. Encouraged by thesewide variety of applications, we thought it might be interesting to link coumarin molecule with the biologically active IT moiety expecting a molecule with enhanced biological activity. These molecules were prepared as precursors during the synthesis of potential antidiabetic thiazolidine-2,4-dione derivatives of IT. 
The title compound was synthesized using Vilsmeier-Haack reagent which was made to react with the prepared 3-(2-cyclohexylimidazo[2,1-b] $[1,3,4]$ thiadiazol-6-yl)-2H-chromen-2-one. This was followed by measurement of analytical data relating to the compound.

The compound was then subjected to spectroscopic analysis using IR and ${ }^{1} \mathrm{H}$ NMR techniques to confirm the presence of the supposed ring system, formylation at the appropriate position and the signals for the existence of aldehydic and other protons.

A single crystal X-ray diffraction analysis was carried out on the compound to investigate the geometry of the coumarin moiety and also possible contributions like intramolecular interactions towards the stabilization of the molecule. The analysis revealed certain interesting features like the individual planarity of the two ring systems despite the presence of non-planarity in their combined structure. Also, the cyclohexyl ring is found to be in chair conformation. No interesting intramolecular hydrogen bonding is observed, although there is an infinite zigzag pattern of linkage between molecules, brought about by several directionally specific $\mathrm{C}-\mathrm{H}$. . . O interactions.

\section{Experimental}

\section{Synthesis and characterization}

The title compound was prepared in two stages as shown in Scheme 1. The reaction of 2-amino-5-cyclohexyl-1,3,4-thiadiazole ${ }^{10}$ (1) and 3-bromoacetyl coumarin $^{11}(2)$ in boiling ethanol afforded 3-(2-cyclohexylimidazo[2,1-b]$[1,3,4]$ thiadiazol-6-yl)- $2 H$-chromen-2-one (3) as hydrobromide salt, which was neutralized by sodium carbonate solution to get the free base. It was subjected to Vilsmeir Haack reaction to yield 2-cyclohexyl-6- (2-oxo-2H-chromen-3-yl) imidazo $[2,1-b][1,3,4]$ thiadiazole-5-carbaldehyde (4). The structures of the synthesized compounds were established by analytical and spectral data.

3-(2-cyclohexylimidazo[2,1-b]- [1,3,4]thiadiazol-6-yl)-2H-chromen-2-one (3). Equimolar quantities of 2-amino-5-cyclohexyl-1,3,4thiadiazole (1.83 g, $0.01 \mathrm{~mol})$ and 3-bromoacetyl coumarin $(2.67 \mathrm{~g}, 0.01 \mathrm{~mol})$ were refluxed in absolute ethanol for $8 \mathrm{~h}$. The resultant solid (hydrobromide) was separated by filtration. The free base was obtained by neutralization with sodium carbonate solution. It was washed with<smiles>Nc1nnc(C2CCCCC2)s1</smiles>

1<smiles>CC(=O)OCc1cc2cc(C(=O)CBr)c(=O)oc2cc1CC1CC1</smiles>

2<smiles>O=c1oc2ccccc2cc1-c1cn2nc(C3CCCCC3)sc2n1</smiles>

3 $\mathrm{DMF} / \mathrm{POCl}_{3}$<smiles>O=Cc1c(-c2cc3ccccc3oc2=O)nc2sc(C3CCCCC3)nn12</smiles> 
water and recrystallised from alcohol as an yellow amorphous solid. (Compound 3: Yield 58\%; mp 182-184 ${ }^{\circ} \mathrm{C}$ ).

2-cyclohexyl-6- (2-oxo-2H-chromen-3-yl) imidazo [2,1-b][1,3,4] thiadiazole-5-carbaldehyde (4). Vilsmeier- Haack reagent was obtained by adding $\mathrm{POCl}_{3}(3 \mathrm{ml})$ in DMF $(20 \mathrm{ml})$ at $0^{\circ} \mathrm{C}$, with stirring. Compound 3 (3.51 g, $0.01 \mathrm{~mol}$ ) was added to the reagent and stirred at $0^{\circ} \mathrm{C}$ for $30 \mathrm{~min}$. The mixture was further stirred at room temperature for $2 \mathrm{~h}$ and at $60^{\circ} \mathrm{C}$ for additional $2 \mathrm{~h}$. The reaction mixture was then poured into sodium carbonate solution and stirred at $90^{\circ} \mathrm{C}$ for $2 \mathrm{~h}$. After cooling, the mixture was diluted with water, extracted with chloroform and the chloroform extracts were washed with water, dried over anhydrous sodium sulphate. The solvent was removed under reduced pressure to yield the residual solid, which was recrystallised from chloroform and hexane mixture $(90: 10)$ to get pale yellow crystalline solid. (Compound 4: Yield 66\%; mp. $176-178^{\circ} \mathrm{C}$ ).

\section{Physical measurements}

Melting points were determined in open capillaries and are uncorrected. IR spectra were recorded on Nicolet FT-IR 410 spectrophotometer. ${ }^{1} \mathrm{H} \quad \mathrm{NMR}$ spectra were recorded on Varian $\mathrm{RX}-300 \mathrm{MHz}$ spectrometer using TMS as internal standard.

The Infrared spectra of imidazo[2,1$b][1,3,4]$ thiadiazole derivatives does not contain absorption band due to $v_{\mathrm{C}=\mathrm{O}}$ (ketone carbonyl of bromoacetyl coumarin), $v \mathrm{NH}_{2}$ and presence of lactone $v_{\mathrm{C}=\mathrm{O}}$ confirming the formation of imidazo $[2,1-b]-[1,3,4]$ thiadiazoles. The ${ }^{1} \mathrm{H}$ NMR spectra $\left(\mathrm{CDCl}_{3}\right)$ showed appropriate signals due to different protons present in the molecule. The formylation products showed a band due to $v_{\mathrm{C}=\mathrm{O}}$ in its IR spectra and a singlet due to aldehyde proton in the NMR spectrum. The absence of singlet due to $C 5-\mathrm{H}$ was considered as the confirmation of formylation at $\mathrm{C}_{5}$.

Compound 3: IR $(\mathrm{KBr}) \mathrm{cm}^{-1} 1734\left(v_{\mathrm{C}=\mathrm{O}}\right.$, lactone), $1600 \quad\left(v_{\mathrm{C}=\mathrm{N}}\right) ;{ }^{1} \mathrm{H} \quad \mathrm{NMR}\left(\mathrm{CDCl}_{3}\right) \quad \delta$,
1.26-3.03 (m, 11H, cyclohexyl), 7.32-7.60 (m, $4 \mathrm{H}$, coumarinyl), 8.57 (s, $1 \mathrm{H}, \mathrm{C}_{4} \mathrm{H}$, coumarin), 8.63 (s, 1H, $\mathrm{C}_{5} \mathrm{H}$ imidazole); Anal.Calcd for, $\mathrm{C}_{19}$ $\mathrm{H}_{17} \mathrm{~N}_{3} \mathrm{O}_{2} \mathrm{~S} ; \mathrm{C}, 64.94 ; \mathrm{H}, 4.88 ; \mathrm{N}, 11.96$; Found; C, 64.85; H, 4.82, N, 11.90.

Compound 4: IR $(\mathrm{KBr}) \mathrm{cm}^{-1} ; 2858\left(v_{\mathrm{C}-\mathrm{H}}\right.$ aldehyde $), \quad 1736\left(v_{\mathrm{C}=\mathrm{O}}\right.$, lactone $), \quad 1676\left(v_{\mathrm{C}=\mathrm{O}}\right.$, aldehyde $) 1601\left(v_{\mathrm{C}=\mathrm{N}}\right) ;{ }^{1} \mathrm{H} \mathrm{NMR}\left(\mathrm{CDCl}_{3}\right) \delta 1.30$ $3.52(\mathrm{~m}, 11 \mathrm{H}$, cyclohexyl), 6.92-7.64 $(\mathrm{m}, 4 \mathrm{H}$, coumarinyl), 8.33 (s, 1H, C4-H coumarin), 10.21 (s, 1H, aldehyde); Anal.Calcd for, $\mathrm{C}_{20} \mathrm{H}_{17} \mathrm{~N}_{3} \mathrm{O}_{3}$ S; C, 63.31; H, 4.52; N, 11.07; found, C, 63.27; $\mathrm{H}, 4.38 ; \mathrm{N}, 11.10$.

\section{Crystal structure determination of (4)}

The X-ray diffraction data were collected on a Bruker Smart CCD Area Detector System using

Table 1. Crystal Data and Structure Refinement

\begin{tabular}{ll}
\hline Empirical formula & $\mathrm{C}_{20} \mathrm{H}_{17} \mathrm{~N}_{3} \mathrm{O}_{3} \mathrm{~S}$ \\
Formula weight & 379.43 \\
Temperature $(\mathrm{K})$ & $293(2)$ \\
Wavelength $(\mathrm{A})$ & 0.71073 \\
Crystal system & Monoclinic \\
Space group & $P 2_{1} / c$ \\
Cell dimensions & \\
$\quad a(\AA)$ & $17.316(3)$ \\
$\quad b(\AA)$ & $6.5420(9)$ \\
$\quad c(\AA)$ & $17.056(3)$ \\
$B\left({ }^{\circ}\right)$ & $112.909(2)$ \\
Volume $\left(\AA^{3}\right)$ & $1779.7(4)$ \\
$Z$ & 4 \\
Density(Calculated $)\left(\mathrm{Mg} / \mathrm{m}^{3}\right)$ & 1.416 \\
Absorption coefficient $\left(\mathrm{mm}^{-1}\right)$ & 0.209 \\
$F(000)$ & 792 \\
Crystal size & $0.1 \mathrm{~mm} \times 0.2 \mathrm{~mm} \times 0.25 \mathrm{~mm}$ \\
$\Theta$ range for data collection & 2.40 to $27.99^{\circ}$ \\
Index ranges & $-22<=\mathrm{h}<=22$ \\
& $-8<=\mathrm{k}<=8$ \\
& $-22<=1<=22$ \\
Reflections collected & 14876 \\
Independent reflections & $4234[R($ int $)=0.0306]$ \\
Refinement method & Full-matrix least-squares on $F^{2}$ \\
Data/restraints/parameters & $4234 / 0 / 268$ \\
Goodness-of-fit on $F^{2}$ & 1.128 \\
Final $R$ indices $[I>2$ sigma $(I)]$ & $R_{1}=0.0601, \mathrm{wR}_{2}=0.1222$ \\
$R$ indices (all data) & $R_{1}=0.0862, \mathrm{wR} 2=0.1316$ \\
Largest diff. peak and hole & 0.313 and -0.218 \\
$\quad\left(\mathrm{e}\right.$. A $\left.{ }^{-3}\right)$ & \\
CCDC deposit no. & 271066. \\
\hline & \\
\hline &
\end{tabular}


Mo-K $\alpha$ radiation $(\lambda=0.71073 \AA)$, to $\theta_{\max }$ of $28.0^{0}$ in $\omega-\Phi$ scan mode. The data were processed using SAINTPLUS ${ }^{12}$ and absorption corrections were applied in $\mathrm{SADABS}^{13} \mathrm{~A}$ total of 14876 reflections was collected, resulting in $4234\left(R_{\text {int }}=0.031\right)$; of these, the number of 'observed' reflections (with $I>2 \sigma(I)$ ) was 3218. Corrections for Lorentz and polarization effects were applied. The structure was solved by direct methods and difference Fourier synthesis using SHELXS97. ${ }^{14}$ The posi-

Table 2. Selected Bond Lengths $[\AA]$ and Angles $\left[{ }^{\circ}\right]$

\begin{tabular}{ll}
\hline $\mathrm{S}(1)-\mathrm{C}(8)$ & $1.721(2)$ \\
$\mathrm{S}(1)-\mathrm{C}(2)$ & $1.762(2)$ \\
$\mathrm{N}(3)-\mathrm{C}(2)$ & $1.295(2)$ \\
$\mathrm{N}(3)-\mathrm{N}(4)$ & $1.375(2)$ \\
$\mathrm{O}(14)-\mathrm{C}(15)$ & $1.378(3)$ \\
$\mathrm{O}(14)-\mathrm{C}(12)$ & $1.383(2)$ \\
$\mathrm{N}(4)-\mathrm{C}(8)$ & $1.349(3)$ \\
$\mathrm{N}(4)-\mathrm{C}(5)$ & $1.388(2)$ \\
$\mathrm{O}(13)-\mathrm{C}(12)$ & $1.197(2)$ \\
$\mathrm{O}(10)-\mathrm{C}(9)$ & $1.211(3)$ \\
$\mathrm{C}(6)-\mathrm{N}(7)$ & $1.376(3)$ \\
$\mathrm{C}(6)-\mathrm{C}(5)$ & $1.384(3)$ \\
$\mathrm{C}(21)-\mathrm{C}(11)$ & $1.338(3)$ \\
$\mathrm{N}(7)-\mathrm{C}(8)$ & $1.322(3)$ \\
$\mathrm{C}(8)-\mathrm{S}(1)-\mathrm{C}(2)$ & $88.0(1)$ \\
$\mathrm{C}(2)-\mathrm{N}(3)-\mathrm{N}(4)$ & $108.0(2)$ \\
$\mathrm{C}(15)-\mathrm{O}(14)-\mathrm{C}(12)$ & $122.3(2)$ \\
$\mathrm{C}(8)-\mathrm{N}(4)-\mathrm{N}(3)$ & $118.5(2)$ \\
$\mathrm{C}(8)-\mathrm{N}(4)-\mathrm{C}(5)$ & $107.7(2)$ \\
$\mathrm{N}(3)-\mathrm{N}(4)-\mathrm{C}(5)$ & $133.8(2)$ \\
$\mathrm{N}(7)-\mathrm{C}(6)-\mathrm{C}(5)$ & $112.2(2)$ \\
$\mathrm{N}(7)-\mathrm{C}(6)-\mathrm{C}(11)$ & $118.6(2)$ \\
$\mathrm{C}(5)-\mathrm{C}(6)-\mathrm{C}(11)$ & $129.2(2)$ \\
$\mathrm{C}(21)-\mathrm{C}(11)-\mathrm{C}(6)$ & $121.4(2)$ \\
$\mathrm{C}(12)-\mathrm{C}(11)-\mathrm{C}(6)$ & $118.0(2)$ \\
$\mathrm{N}(3)-\mathrm{C}(2)-\mathrm{C}(22)$ & $124.7(2)$ \\
$\mathrm{N}(3)-\mathrm{C}(2)-\mathrm{S}(1)$ & $116.2(1)$ \\
$\mathrm{C}(22)-\mathrm{C}(2)-\mathrm{S}(1)$ & $119.0(1)$ \\
$\mathrm{O}(13)-\mathrm{C}(12)-\mathrm{O}(14)$ & $116.7(2)$ \\
$\mathrm{O}(13)-\mathrm{C}(12)-\mathrm{C}(11)$ & $126.4(2)$ \\
$\mathrm{O}(14)-\mathrm{C}(12)-\mathrm{C}(11)$ & $116.9(2)$ \\
$\mathrm{O}(14)-\mathrm{C}(15)-\mathrm{C}(16)$ & $117.8(2)$ \\
$\mathrm{O}(14)-\mathrm{C}(15)-\mathrm{C}(20)$ & $120.5(2)$ \\
$\mathrm{C}(6)-\mathrm{C}(5)-\mathrm{N}(4)$ & $103.4(2)$ \\
$\mathrm{N}(4)-\mathrm{C}(5)-\mathrm{C}(9)$ & $122.4(2)$ \\
$\mathrm{C}(8)-\mathrm{N}(7)-\mathrm{C}(6)$ & $103.6(2)$ \\
$\mathrm{O}(10)-\mathrm{C}(9)-\mathrm{C}(5)$ & $123.7(2)$ \\
$\mathrm{N}(7)-\mathrm{C}(8)-\mathrm{N}(4)$ & $113.0(2)$ \\
$\mathrm{N}(7)-\mathrm{C}(8)-\mathrm{S}(1)$ & $137.6(2)$ \\
$\mathrm{N}(4)-\mathrm{C}(8)-\mathrm{S}(1)$ & \\
\hline &
\end{tabular}

tions of all non-hydrogen atoms were included in the full-matrix least-square refinement using SHELXL97. ${ }^{15}$ Anisotropic refinement using fullmatrix least-square procedures was carried out for a few cycles until convergence was reached. The hydrogen atoms were fixed geometrically; those on the coumarin moiety and in the aldehyde group were then refined freely, while the remainder were set to ride on the parent carbon atoms. The final $R$ factors were $\mathrm{wR}_{2}=0.132$ and $R_{l}=0.086$ for all 4234 reflections, and $R_{l}=0.060$ for the 'observed' data; the maximum and the minimum values of residual electron density were 0.3 and $-0.2 \mathrm{e}^{-3}$. Molecular diagrams were generated using ORTEP. ${ }^{16}$ The details of crystal data and refinement are given in Table 1.

\section{Results and discussion}

The selected bond distances and angles are given in Table 2. Table 3 shows the selected torsion angles. The ORTEP diagram of the molecule is shown in Fig. 1.

The bond lengths and angles in 4 are within normal ranges. ${ }^{17}$ The angle between the IT group and the coumarin moieties is $48.14(2)^{\circ}$, showing deviation from planarity, as observed for other coumarin derivatives. ${ }^{18,19}$ The two ring systems are each planar.

Table 3. Selected Torsion Angles $\left[{ }^{\circ}\right]$

\begin{tabular}{lc}
\hline $\mathrm{N}(7)-\mathrm{C}(6)-\mathrm{C}(11)-\mathrm{C}(21)$ & $-46.3(3)$ \\
$\mathrm{C}(5)-\mathrm{C}(6)-\mathrm{C}(11)-\mathrm{C}(21)$ & $136.4(2)$ \\
$\mathrm{N}(7)-\mathrm{C}(6)-\mathrm{C}(11)-\mathrm{C}(12)$ & $126.5(2)$ \\
$\mathrm{C}(5)-\mathrm{C}(6)-\mathrm{C}(11)-\mathrm{C}(12)$ & $-50.8(3)$ \\
$\mathrm{C}(27)-\mathrm{C}(22)-\mathrm{C}(2)-\mathrm{N}(3)$ & $-114.1(2)$ \\
$\mathrm{C}(23)-\mathrm{C}(22)-\mathrm{C}(2)-\mathrm{S}(1)$ & $-169.65(15)$ \\
$\mathrm{C}(6)-\mathrm{C}(11)-\mathrm{C}(12)-\mathrm{O}(13)$ & $1.1(3)$ \\
$\mathrm{C}(6)-\mathrm{C}(11)-\mathrm{C}(12)-\mathrm{O}(14)$ & $-177.52(17)$ \\
$\mathrm{C}(11)-\mathrm{C}(6)-\mathrm{C}(5)-\mathrm{N}(4)$ & $176.67(18)$ \\
$\mathrm{N}(7)-\mathrm{C}(6)-\mathrm{C}(5)-\mathrm{C}(9)$ & $174.5(2)$ \\
$\mathrm{C}(11)-\mathrm{C}(6)-\mathrm{C}(5)-\mathrm{C}(9)$ & $-8.1(4)$ \\
$\mathrm{C}(8)-\mathrm{N}(4)-\mathrm{C}(5)-\mathrm{C}(9)$ & $-175.33(18)$ \\
$\mathrm{N}(3)-\mathrm{N}(4)-\mathrm{C}(5)-\mathrm{C}(9)$ & $6.0(3)$ \\
$\mathrm{C}(6)-\mathrm{C}(5)-\mathrm{C}(9)-\mathrm{O}(10)$ & $-6.3(4)$ \\
$\mathrm{N}(4)-\mathrm{C}(5)-\mathrm{C}(9)-\mathrm{O}(10)$ & $168.16(19)$ \\
\hline
\end{tabular}




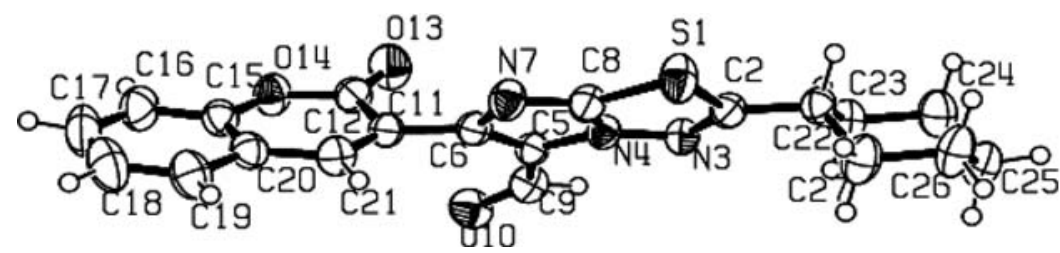

Fig. 1. The molecular structure and atom labeling scheme of the title compound.

The coumarin skeleton geometry can be compared with that of unsubstituted coumarin. 20 of coumarin-3-carboxylic acid ${ }^{21}$ and of 3-(bromoacetyl) coumarin. ${ }^{22}$ The double-bond character of $\mathrm{C} 11-\mathrm{C} 21$ is observed in all these compounds. The $\mathrm{C} 12-\mathrm{C} 11$ and $\mathrm{C} 21-\mathrm{C} 20$ bonds, adjacent to the double bond, are systematically longer than $1.40 \AA$ in these four molecules. The angles C16-C15-O14 and C19-C20-C21 at the junction of the two rings are, respectively, smaller and greater than $120^{\circ}$. The angles around C12 follow the same behavior in all the compounds.

Compared with unsubstituted coumarin, ${ }^{20}$ the decrease in the $\mathrm{C} 12-\mathrm{C} 11-\mathrm{C} 21$ bond angle by $2^{\circ}$ and increase in $\mathrm{C} 11-\mathrm{C} 21-\mathrm{C} 20$ by the same amount may be due to the IT group substituted at C11.

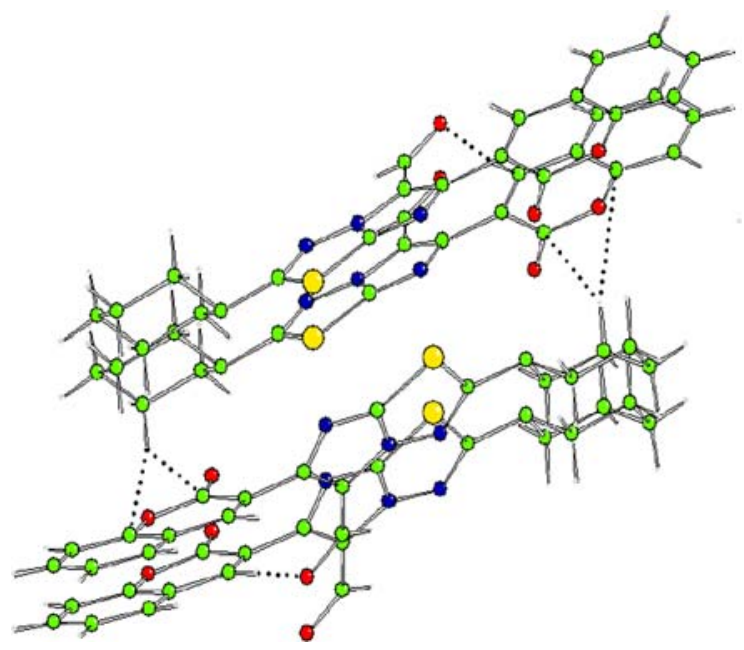

Fig. 2. View of (i) $\mathrm{C}-\mathrm{H}$... O interaction (ii) Intermolecular short contacts between cyclohexyl proton and coumarin ring.
The C12-O13 1.996 (3) A, C12-C11 1.462 (3) $\AA$ and $\mathrm{C} 11-\mathrm{C} 211.337$ (3) $\AA$ distances show conjugation of the $\mathrm{C}-\mathrm{O}, \mathrm{C}-\mathrm{C}$ and $\mathrm{C}=\mathrm{C}$ bonds. Carbaldehyde group is inclined at an angle of $9.77(5)^{\circ}$ to the IT group.

No interesting intramolecular hydrogen bonding is seen in the molecule. However, in this crystal structure, the molecule is linked to its neighbors by several directionally specific C-H. . O interactions $[\mathrm{C} 21-\mathrm{H} 21$. . . O10, C ... O distance being 3.293(3) $\AA$ and C$\mathrm{H}$... O angle being $168(2)^{\circ}$, Fig. 2]. Other significant intermolecular short contacts are between $\mathrm{H} 24 \mathrm{~b}$ of cyclohexane ring and the face of a neighboring coumarin ring with $\mathrm{C} 12 \ldots \mathrm{H} 24 \mathrm{~b}$ and $\mathrm{C} 15 \ldots \mathrm{H} 24 \mathrm{~b}$ distances being 2.881 and $2.891 \AA$ A respectively [Fig. 2].

\footnotetext{
Supplementary material CCDC 271066 contains the supplementary crystallographic data for this paper. These data can be obtained free of charge at www.ccdc.com.ac.uk/conts/retrieving.html or from the Cambridge Crystallographic Data Centre(CCDC), 12 Union Road, Cambridge CB2 1BZ. UK: fax: + 44(0)1223.336033: e-mail:deposit@ccdc.com.ac.uk.
}

\section{Acknowledgments}

N. S. B thanks UGC-DRS for financial support D. E. V thanks UGC-FIP for the Teacher fellowship. The authors thank the Department of Science and Technology, India, for data collection on the CCD facility set up under the IRHPA-DST program.

\section{References}

1. Thienopont, D.C.; Vanparijs, O.F.J.; Raeymaekers, A.H.M.; Vandenberk, J.; Demoen, P.G.A.; Allewijin, F.T.N.; Marsboom, 
R.P.H.; Niemegeers, C.J.E.; Shellekens, K.H.L.; Janssen, A. J. Nature. 1966, 209, 1084.

2. Gadad, A.K.; Mahajanshetti, C.S.; Nimbalkara S.; Raichurkar, A. Eur. J. Med. Chem. 2000, 35, 853.

3. Khazi, I.M.; Mahajanshetti, C.S.; Gadad, A.K.; Tarnalli A.D.; Sultanpur, C.M. Arzneim-Forsch./Drug Res. 1966, 46, 949.

4. Eldwy, A.; Shams, S.A.; El-Dine., El.; Brembaly, K. M. Pharmazie. 1979, 34(3), 144.

5. Spath, E. Ber. 1937, 70, 83.

6. Jois, S.S.; Manjunath, B.L.; Rao, S.V.J.Indian Chem. Soc. 1933, $10,41$.

7. Braon, S.A. Nature. 1961, 194, 372.

8. Wallick, H.; Haris, D.A.; Reagan, M.A.; Ruger, M.; Woodruff, H. Antibiot. Ann. 1956, 909.

9. Childress, S. Topics Med. Chem. 1967, 1, 109.

10. Gadad, A.H.; Khazi, I.M.; Mahajanshetti, C.S.Ind.J.Het.Chem. 1992, 2, 47.

11. Koelsch, C.F. J. Am. Chem. Soc. 1950, 72, 2993.

12. Bruker, SMART (V5.628).; SAINT (V6.02), Program for data reduction, Bruker Axs Inc.Madison, Wisconsin: USA, 1998.
13. Sheldrick, G.M. SADABS, Program for absorption correction, University of Göttingen: Germany, 1996.

14. Sheldrick, G. M. SHELXS97, Program for Crystal Structure Solution, University of Göttingen, Germany, 1997.

15. Sheldrick, G.M. SHELXL97, Program for crystal structure refinement, University of Göttingen: Germany, 1997.

16. Farrugia, L.J. ORTEP-3 for Windows-A Version of ORTEP-111 with a graphical User Interface (GUI), J. Appl. Cryst. 1997, 30 , 565.

17. Allen, F.H.; Kennard, O.; Watson, D.G.; Brammer, L.; Orpen, A.G.; Taylor, R. J. Chem. Soc. Perkin Trans. 1987, S1-19.

18. Chinnakali, K.; Sivakumar, K.; Natarajan, S. Acta Cryst. 1990, C46, 405 .

19. Dhaneshwar, N.N.; Tavale, S.S.; Guru Row, T.N. Acta Cryst. 1988, C44, 1858.

20. Gavuzzo, E.; Mazza, F.; Giglio, E. Acta Cryst. 1974, B30, 1351.

21. Dobson, A.J.; Gerkin, R.E. Acta Cryst. 1996, C52, 3081.

22. Vasudevan, K.T.; Puttaraja Kulkarni, M.V. Acta Cryst. 1991, C47, 775 . 